\title{
French Colonial Conference at Brazzaville
}

THE Colonial Conference at Brazzaville held in January and February 1944 discussed the general principles of native policy, taking as a basis the ideas expressed by Governor General Éboué in his circular letter of 8 November 194r. The question of colonial representation in the future Constitution of France was debated, and three main solutions were examined: the representation of all colonies in the Metropolitan Parliament; the creation of a Colonial Assembly for the purpose of advising the metropolitan Government and the Chamber on all questions pertaining to overseas territories; and the institution of a Federal Assembly composed of Metropolitan and Colonial Representatives, and having deliberative powers on all matters of a federal nature.

\section{Rhodes-Livingstone Institute: Director's Report on the work of the years 1941-3}

THIs report summarizes the work of the Institute since the resignation of Godfrey Wilson in $194 \mathrm{I}$; it includes a statement of the Institute's financial position, a report on the development of the museum and library services, and accounts of the publications issued during the period under review or planned to appear in the near future. Among the latter is a Journal, the aim of which is 'to set out, simply and accurately, the problems-social, ecological, technological, medical etc.- which confront man in Zambezia'. Of exceptional interest is the account given of the Institute's activities in stimulating general public interest in social problems and sociological research by means of correspondence among its members, exchange of information, study and discussion circles. The educational work of the Institute, carried out mainly through the museum, but also in the schools, by means of the circulation of annotated series of photographs and advice regarding books for school use, will be of great and increasing value. The Report records many instances of fruitful co-operation with other institutions, and outlines plans for further research and future development.

\section{Archaeological Discoveries in Senegal}

Dr. M. D. W. Jefrreys writes: "With reference to the note on Archaeological discoveries in Senegal (Africa, July 1943) Mrs. Meyerowitz is incorrect in her statement about the ten "step-pyramids" near the nine mile corner at Enugu. A full description of their origin and dimensions appeared in the Nigerian Field, under the title of "Nsuede Pyramids", April 1935. The dimensions given are: average height, eighteen to nineteen feet; diameter at base, twenty-seven feet. They are not royal tombs and were erected round about 1933 to enhance the name and fame of Uto, the local deity.'

Mrs. Meyerowitz writes: 'Perhaps I did not make it clear that I got the information regarding them from the caption underneath the photograph published in Nigeria.... Back numbers of the Nigerian Field are very difficult to get and that is how I missed the very interesting information of Dr. Jeffreys, which I am certain is correct .' 12 July 1944.

\section{Food Resources of Africa}

Number 3 of the African Handbooks issued by the University of Pennsylvania Press ${ }^{1}$ is a useful compilation dealing with food-crops grown in Tropical and North Africa. The book is divided into sections dealing with West, Equatorial, North-east, and East Africa and French North Africa. Within each section the material is classified under headings such as cereal crops, legumes, root-crops, herbaceous vegetables and fruits, citrous fruits, oil and sugar plants, and other local specialities. Statistics relating to acreage under cultivation, weight of crop grown, and weight exported are given for various territories, together with

I Food Resources of Africa, by Thomas S. Githen and Carroll E. Wood, Jr., University of Pennsylvania

Press and Humphrey Milford, London, 1943, pp. rog. 9s. 6d. 